\title{
Financing sustainable development: Needs and ways
}

\author{
Krishanu Guha Majumder, ${ }^{1, *}$, Manas Chakraborti² \\ ${ }^{1}$ Research Scholar, ${ }^{2}$ Professor, Dept. of Commerce, University of Gour Banga, Malda, West Bengal, India
}

*Corresponding Author: Krishanu Guha Majumder

Email: udaasin@gmail.com

\begin{abstract}
The present article makes an effort to understand, from the student-centric perspective, the notion of sustainable development and the role of Finance therein. Sustainable development, as suggested by Gro Harlem Brundtland, is the "development that meets the needs of the present without compromising the ability of future generations to meet their own needs". Being a continuous process, the sustainable development considers the interaction of the five basic influential factors that actually shape the extent of any development, such as, a) population increase, b) structural change of (agricultural) production, c) depletion of non-renewable resource, d) industrial output, and e) pollution generation. The goals of socio-economic development can be defined by sustainability objectives in all countries - developed or developing, market-oriented or centrally planned. Without proper financing instrument there can be no probable conformity on achieving the goals and objectives of sustainable development, and without any explicitly defined goals, no guidance can be made to design a financing framework intended for sustainable development. The chapter is divided into four sub-chapters. The first two sub-chapters try to briefly describe the paradigm of sustainable development and its basic dimensions. The third and fourth sub-chapters respectively attempt to brief the need and the possible ways of finance in the process of sustainable development.
\end{abstract}

Keywords: Agenda 21, Agenda 2030, Brown Agenda, Official Development Assistance (ODA), Other Official Flows (OOF), PublicPrivate Partnership (PPP), Sustainable development, Sustainable Development Goals (SDGs), Remittances.

\section{Paradigm of Sustainable Development}

In the 'An Essay on the Principle of Population' (1798), the famous political economist Thomas Malthus questioned whether the scarce natural resources may able to provide enough support for the budding population as population is likely to grow in a geometric progression while the subsistence can simply grow in an arithmetic progression. Malthus opined about the essential ideas of environmentalism (Dixon \& Fallon, 1989). But until the recent decades, the human civilisation was concerned only with the 'efficiency of resource use' rather 'efficient allocation of resources' which merely ignored the possibilities of resource depletion and, in point of fact, this resulted in resource scarcity and pollution (Freeman, 1973). Scarcities of non-renewable natural resources are becoming simply worrying for the long term economic growth by limiting the factors of production. In recent decades global concern has emerged regarding the sustainability of development.

In 1970 a team of researchers guided by Donald Meadows and Donella Meadows grouped at the Massachusetts Institute of Technology to study the interaction of five basic influential factors that actually shape the extent of development, such as, a) population increase, b) structural change of (agricultural) production, c) depletion of non-renewable resource, d) industrial output, and e) pollution generation.

The MIT team used data on these five factors into a global computer model, named 'World 3', and then tested the behaviour of the model under several sets of assumptions to find out different patterns for mankind's future. It was assumed on basis of past trend that population, industrial production and pollution would continue to grow exponentially in the future. With help of such computer simulated model the team suggested that as the natural resources are not finite, exponential growth of these three key phenomena, i.e., growth of population, industrial production and pollution, must eventually come to an edge. If resources are not used efficiently in near future then our planet earth will definitely become a poor, crowded, hungry and a polluted solitary.

There are distinct existences of 'feedback loops and other interconnections' between the five main sectors of the World 3 model as presented in 'The Limits to Growth'. The model again suggests that there are evident of 'selfreinforcing feedback loops' between the population and the capital sectors, and the logic is simple, increasing population demands more and more supply of effectual equipments able for producing goods and services which again triggers demand for more of such equipments virtuous cycle (Fig. 1). 


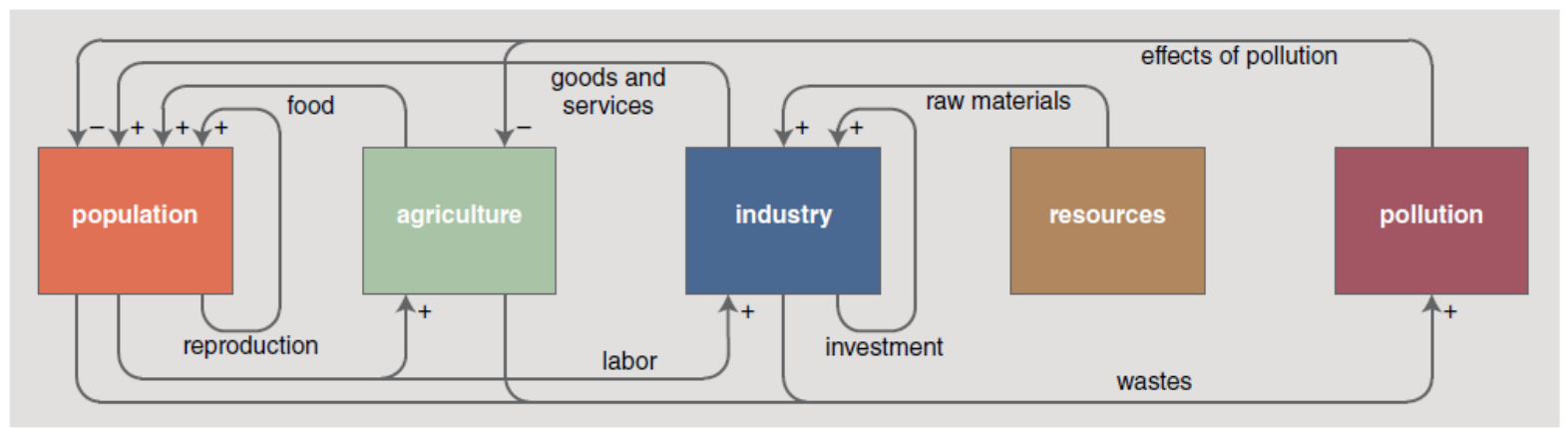

Source: Brian Hayes (Hayes, 2012)

Fig. 1: The interaction of the factors of the 'World 3' model.

Output of the World 3 model tries to mark out the state of affairs of the key variables over the period 1900-2100. The Fig. 2 shows the benchmark situation based on the best possible assessment of the primary condition as envisaged by the researchers. Population and other economic activities (such as industrial output, service output, food per capita etc.) grow or at least stay at a stable situation right through the 20th Century but with a propensity to disintegrate around the middle of the $21^{\text {st }}$ Century as the non-renewable resources will be severely exhausted. An increasing tendency of pollution associated crisis will definitely worsen the situation (Meadows, Meadows, Randers, \& Behrens III, 1972); (Hayes, 2012). The intrinsic advice as suggested by the World 3 model is that to prevent the misfortune we should opt for policies which shall ensure population stabilization, recycling, efficient use of the scarce resources, minimum ecological disruption with maximum conservation - thus ensure a sustainable society with provision of best possible satisfaction of its members (Goldsmith, 1974).

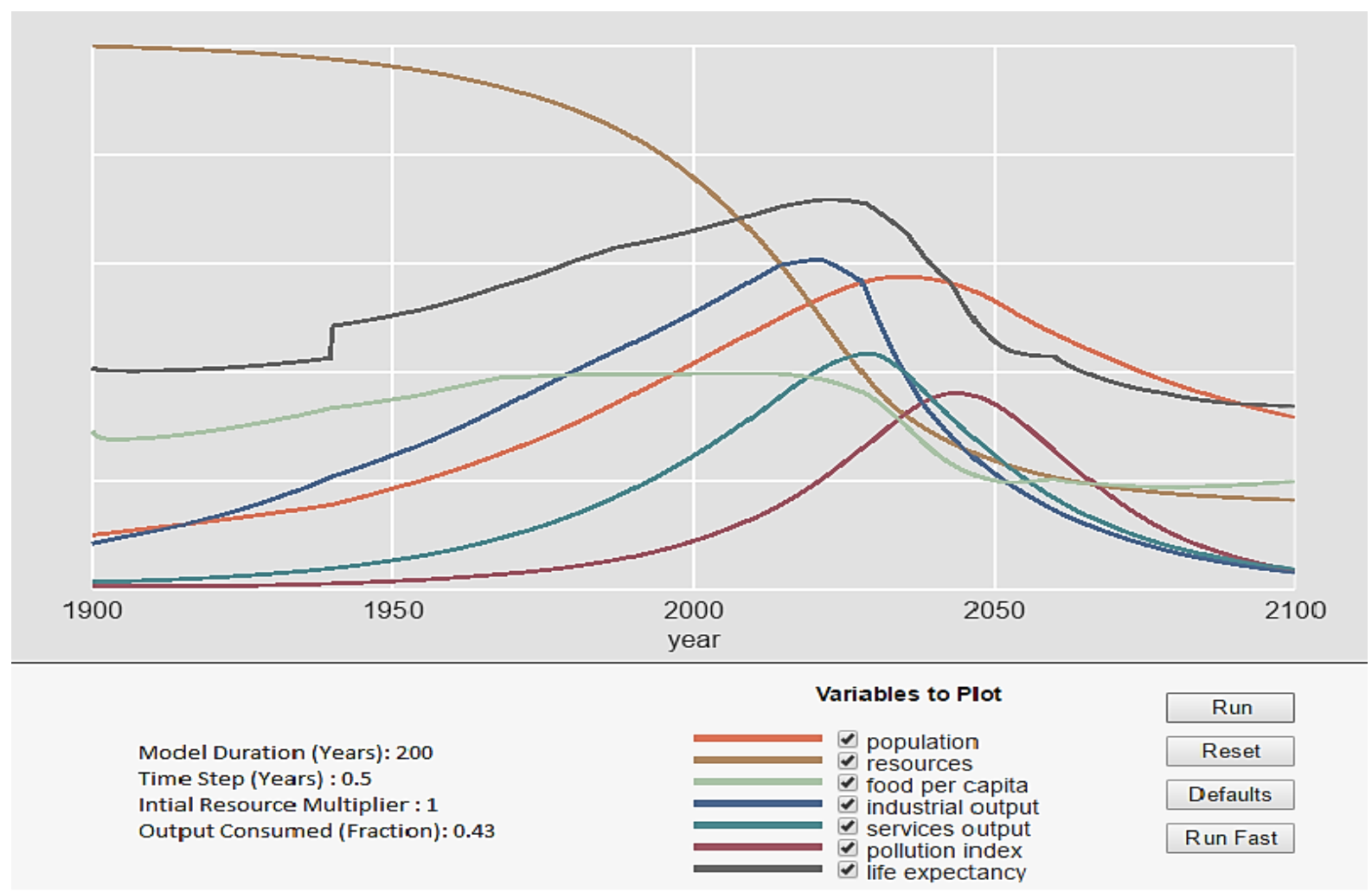

Source: Brian Hayes (Hayes, 2012)

\section{Fig. 2: World 3 Model - a likely situation of key variables over the period 1900-2100}

In the early 1970s, Herman Daly proposed a 'holistic' vision of economics upon which every bit of contemporary 'sustainability' thinking is based on. Herman Daly developed a model, called 'Steady State Economics', intermingling the arguments as asserted in The Limits To Growth (the non-technical report of the World 3 Model), theories of welfare economics, ecological principles, and the philosophy of sustainable development. A 'steady-state economy' tries to achieve a state of equilibrium without exhausting the environment as well as polluting it beyond the threshold (CASSE). 
In 1987, 'Our Common Future', the Report of the UN's world commission on environment and development chaired by Gro Harlem Brundtland, suggested the most timehonoured and much-admired definition of 'sustainable development' as 'development that meets the needs of the present without compromising the ability of future generations to meet their own needs ... thus the goals of economic and social development must be defined in terms of sustainability in all countries - developed or developing, market-oriented or centrally planned" (WCED, 1987).

\section{Dimensions of Sustainable Development}

In 1992, the 'Earth Summit' (the UN's conference on environment and development in Rio de Janeiro) suggested that the sustainable development is the integrated form of economic growth and environmental protection. The "Earth Summit' had proposed an action agenda, named as 'Agenda 21 ', which are to be executed at local, national, and global levels by the UN, other multilateral organizations, and individual governments around the world. The Agenda 21 (which has been considered as "a non-binding and voluntarily implemented 'action plan' of the United Nations with regard to sustainable development") is "a blueprint on how to make development socially, economically and environmentally sustainable".

Agenda 21 suggests equity, entrepreneurship and effectual technology transfer as real measures for achieving 'sustainability' in regard to the socio-economic aspects (UNSD, 1992). Agenda 21 also proposes a number of tangible strategies to bring about 'sustainability' in the environmental realm. Agenda 21 advises for $(a)$ appropriate technology to ensure make use of energy-efficient, nonpolluting and labour-intensive technology utilizing local resources; (b) urban renewal to improve the hygienic conditions of urban slums, to help in job creation and housing, to promote cities safe to natural disasters, to ensure municipal development intended to lessen commuting, and to make sure of implementing effective land use planning concerning urban sprawl which shall prevent it from impinging agricultural land and articulated environmentally sensitive areas; and (c) transport reform that support public commute, bicycling, and foot transport than use of excessive private automobiles ( (Basiago, 1999), (Keating, 1994), (UNSD, 1992)).

The paradigm of 'sustainable development', as discussed in Agenda 21, has two major dimensions, viz., (a) Social \& Economic dimension and $(b)$ Environmental (conservation and resource management) dimension (UNSD, 1992). The paradigm of 'sustainable development' is based on three broad insights namely, economic, social and environmental sustainability (Pawłowski, 2007).

Economic sustainability suggests the stipulation where economic growth sustained by efficient market allocation of resources, production process, consumption and the wellbeing will 'trickle down' to the poor with negligible adverse effect on other resources. Social sustainability puts forward the idea of equality, participation (voice and influence), identity, empowerment and institutional stability.
Environmental sustainability considering integrity within the ecosystem, carrying capacity and biodiversity suggests that natural resources should not be harvested beyond the critical minimum threshold where it cannot be regenerated as well as suitable measures are to be taken regarding waste management to limit the pollution ( (Basiago, 1999), (Kahn, 1995) (UNSD, 1992)).

This in turn suggests, at least theoretically, that the notion of 'sustainable development' for a 'sustainable society' requires the integrated interplay among the equality, the economy and the ecology. Potent economic condition of a region by means of job creation can provide greater opportunity for capital accumulation which can be used for further savings and consumptions that facilitate poverty alleviation to ensure societal equality. This societal equality again endows impetus for better standard of living, education, health, food and nutrients along with consciousness about the nature which are certainly indispensable for generate enough collective intellect requisite for invention and innovation in production technology to preserve the environment and to sustain productivity and so on (Basiago, 1999). Only by efficient integration of the economic, social and environmental aspects, which can informally referred to as the profit, the people and the planet, the way for sustainable development can be found.

There is a converse argument, namely the 'Brown Agenda'. This is an attempt to highlight the environmental and developmental debates concerning developing countries. This is also a theoretical effort to deal with the separate points of view regarding the global 'green' environmental problems and the issues particularly faced up by the urban areas. Here the justification for an urban focus is clear as the 'Brown Agenda' in a few words refers to $(a)$ availability and accessibility of safe drinking water, sanitation, and scientific drainage system; $(b)$ insufficient management of solid and hazardous waste as well as pollution of air, water etc. due to unrestrained emissions from motor vehicles, factories, and low grade domestic fuels. The 'Brown Agenda' ascribes that the escalating environmental destruction can be best possibly managed through integrated economic development and the development of 'social capital'. It is observed that most of the intense environmental degradations are usually take places in areas of high poverty and low social consistency. Thus, it is expected that augmentation of social capital through development will certainly ensure a better environment (McKenzie, 2004) (Agarwal \& Narain, 1992) (Geography).

The environmental and the economic dimensions of sustainable development have been mostly discussed by the decision makers and in the academic literature regarding the sustainability paradigm (Drakakis-Smith, 1995). There may be two possible reasons behind such uneven prioritisation among the dimensions of sustainability. Firstly, the notion of sustainable development was emerged due to synergism between the emerging environmental movement of the 1960s and the world wide campaigns for 'basic need' during 
the 1970s; Secondly, evaluation of the intangible nature of various social aspects of development is associated with some 'measurement quandary' (Colantonio A. , Traditional and Emerging Prospects in Social Sustainability, 2008). Social aspects of sustainability have been integrated only starting with the 1990s (Colantonio A. , 2007).

However, apart from these three dimensions another dimension can be envisaged which plays a crucial role social sustainability and that is the 'institutional dimension', whether it is government institution or private institution or alliance of both (Sengupta \& Baranwal, 2012) (Fig. 3). Some scholars also discuss about other dimensions of urban sustainability such as the moral, the technical, the legal and the political dimension (Pawłowski, 2007).

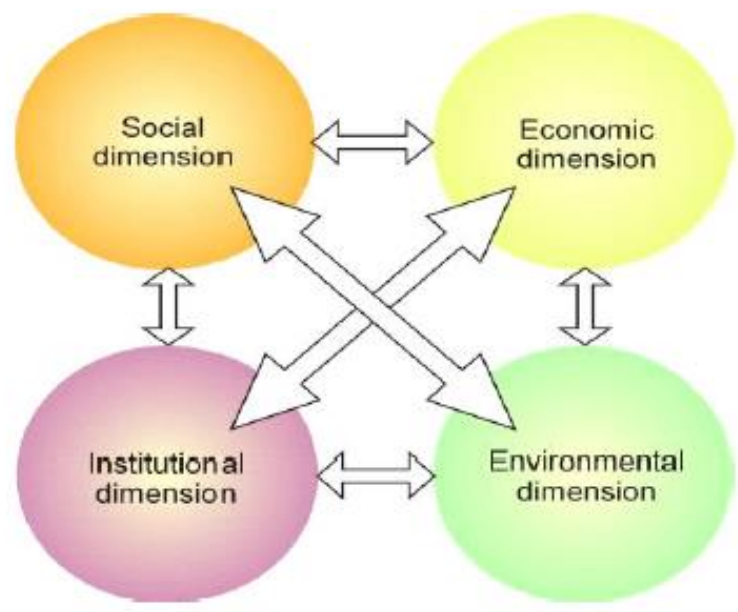

Source: Sengupta \& Baranwal, 2012

Fig. 3: Dimensions of sustainable development

\section{Finance for Sustainable Development}

McKenzie pointed out the most extreme criticism of the Brundtland definition of sustainable development agenda by stating that when sustainable development is vaguely defined to meet the needs of all (including future) stakeholders it often disguise 'businesses' that can continue its operations without hindrance by environmental concerns just by paying mere 'lip services' to the needs of future generations (McKenzie, 2004). Alike observations was made by Michael Jacobs that the definition slackly allows 'business and 'development' interests (and their government supporters) to claim that they are in favour of sustainable development when actually they are the perpetrators of unsustainably' (Jacobs, 1999).

During the 1980s some adverse social issues were observed worldwide with regard to the conventional developmental strategies aimed for poverty alleviation in the course of economic growth (for example, International Monetary Fund and the World Bank took many initiatives to finance significant improvements in developing countries to better their economic conditions, as well as for roads construction, building hydroelectric dams, power plants etc.). These led to a universal consensus that social disparities in developing nations were aggravated by upsetting biodiversity due to such developmental works.
Consequently it has been established that development should be well thought-out within the structure of social and environmental aspects (Basiago, 1999).

Perfect and balanced amalgamation of the "determined economic policies of individual countries at national level' with the "dynamic and accommodating environment of international relationship" is obligatory to attain the Sustainable Development Goals (SDGs). The process of development may be potentially stalled if any one of the following instances (or both) happen (a) the global economy be deficient in dynamism and stability with overwhelmed uncertainties; and /or (b) the developing countries are weighted down by external indebtedness or the finance is inadequate or due to internal policy blockades the marketaccessibility are limited or the terms of trade and the commodity prices developing countries are unfavourable. During the $80 \mathrm{~s}$, almost all these negative issues were seen worldwide. Thus, for achieving global progress, en route for sustainable development, it is felt pre-requisite to plan and revise the international (financial) cooperation to balance domestic economic policies.

At the UN sustainable development summit in 2015, the Agenda 2030 (a set of 17 Sustainable development goals), have been agreed on. Agenda 2030 considers all the SDGs set by Agenda 21 and re-asserts them as the centre for sustainable development by revolving around the concepts of 'people, planet, prosperity, peace, and partnership'. These SDGs cover social and economic development issues such as poverty, hunger, health, education, globalwarming, gender-equality, water, sanitation, energy urbanisation, environment and social justice.

The developing countries, particularly, are in need of new and additional financial resources for sustainable development by realizing the developmental and environmental objectives. Financial resources also are required for reinforcing the capacity of international institutions. Agenda 21 specifically suggests that to effectively carry out of the identified 'programme areas', attention should be given to the particular situations where the economies are in transition (United Nations, 2015).

The Agenda 21 as well as the Agenda 2030 explicitly advocate for 'Strengthen the means of implementation and revitalize the Global Partnership for Sustainable Development' (United Nations, 2015) which envelopes aspects such as capacity building by augmentation of science, technology transfer, education, terms of trade, multi-stakeholder partnerships and financial mechanisms.

Agenda 2030 has set the 'Goal 17', having equal importance with the other Goals and targets, to meet the requirements of the framework for ideally revitalized Global Partnership aiming sustainable development (United Nations, 2015). This 'Goal 17 ' is authoritatively supported by the actual policies and actions suggested in the third international conference on financing for development, held in Addis Ababa during 13 to 16 July 2015. By its resolution 69/313 on 27 July 2015 the General Assembly adopted the Addis Ababa Action Agenda (UN General Assembly, 2015). 
Considering the importance of International Public Finance in harmony with the efforts to mobilize public resources, particularly for the countries with limited domestic resources, necessary suggestions have been made for using international public finance to catalyse additional resource mobilization from other public as well as private sources (United Nations, 2015). Accordingly, several developed countries remain to their commitments to accomplish the target of $0.70 \%$ of their individual 'Gross National Income for Official Development Assistance' (ODA / GNI) to Developing Countries and $0.15 \%$ to $0.20 \%$ of 'ODA / GNI' to the Least Developed Countries (United Nations, 2015).

In the Seventieth Session of the UN-General Assembly (A/RES/70/1), it has also been suggested that each country (irrespective of stages of development) has prime responsibility to retain sustainable development in economic and social aspects for its own and for others as well. And apart from financial resource mobilization, such responsibilities essentially 'include capacity building and transfer of environment-efficient technologies on mutually agreed concessional and preferential terms' (United Nations, 2015). This, in reality, requires augmentation of the "NorthSouth, South-South and Triangular regional and international' cooperation for accessing scientific, technological invention and innovation as well as enhanced knowledge sharing (United Nations, 2015). In this regard, especially for capacity-building, the varied private sectors (ranging from micro-enterprises to cooperatives to multinationals), and the civil society organizations along with the philanthropic organizations can play very important and efficacious role (UN General Assembly, 2015) .

The respective national parliaments also have indispensable role in financial resource mobilization, capacity-building, technology transfer, trade for achieving the sated Sustainable Development Goals (SDGs) through their enactment of legislation and adoption of budgets and improving their role in ensuring accountability.

\section{Ways of Financing Sustainable Development}

Interestingly, without a sound financing mechanism there is no credible conformity on achieving the SDGs, moreover without the SDGs, no guidance can be framed on how to design an effective financing framework for sustainable development (Guido \& Sachs, 2015).

Schmidt-Traub and Sachs suggested ten principal investment areas taking into consideration of the major investment needs for the SDGs, viz., (1) Health; (2) Education; (3) Sustainable agriculture, nutrition, and food systems; (4) Biodiversity and ecosystem services; (5) Water supply and sanitation; (6) Energy access and Sustainable Energy for All; (7) Monitoring and a data revolution for sustainable development; (8) Climate finance; (9) Financing large-scale infrastructure; (10) Public-private Technology Partnerships. However, Schmidt-Traub and Sachs opine that these investment areas are not exhaustive as sustainability objective like 'achieving gender equality and ending violence against girls and women' will require broader measures (Sachs \& Schmidt-Traub, 2013).

Schmidt-Traub and Sachs also suggested that there should be a bottom-up approach for achieving the SDGs, such as the global financial architecture should assess and take into consideration of requirement of new and additional financial resources to the areas as prioritized by the local communities, local governments, sub-national divisional governments, countries, and regions etc. The fundamental aim for financing sustainable development is to create a structure where "long-term saving flows reliably to highpriority, long-term, sustainable investments" (SchmidtTraub, 2015).

The Intergovernmental Committee of Experts on Sustainable Development Financing (ICESDF: UN 2014) has described such investment challenge in the 'Domestic Enabling Environment and Policy Framework' which proposes the flow of funds from a variety of sources for sustainable development (Fig. 4). This framework suggests that first of all, the private and public financing from domestic and international sources be organized and intermediated; and secondly, the domestic and international policies be taken in order to provide constructive background for public and private investments.

Now, in broad sense, there are two basic forms of financing firstly, the private commercial funding seeking market-rate return, and / or secondly, the non-commercial funding from governments and also from private providers who are willing to accept no or below-market rates of return (Schmidt-Traub, 2015).

Private finance responds to private returns, not to social returns and consequently they do not effectively respond to the needs of poor. The poor need public financing to a certain extent than private financing to meet the basic needs and to put up enough capital to escape poverty. 


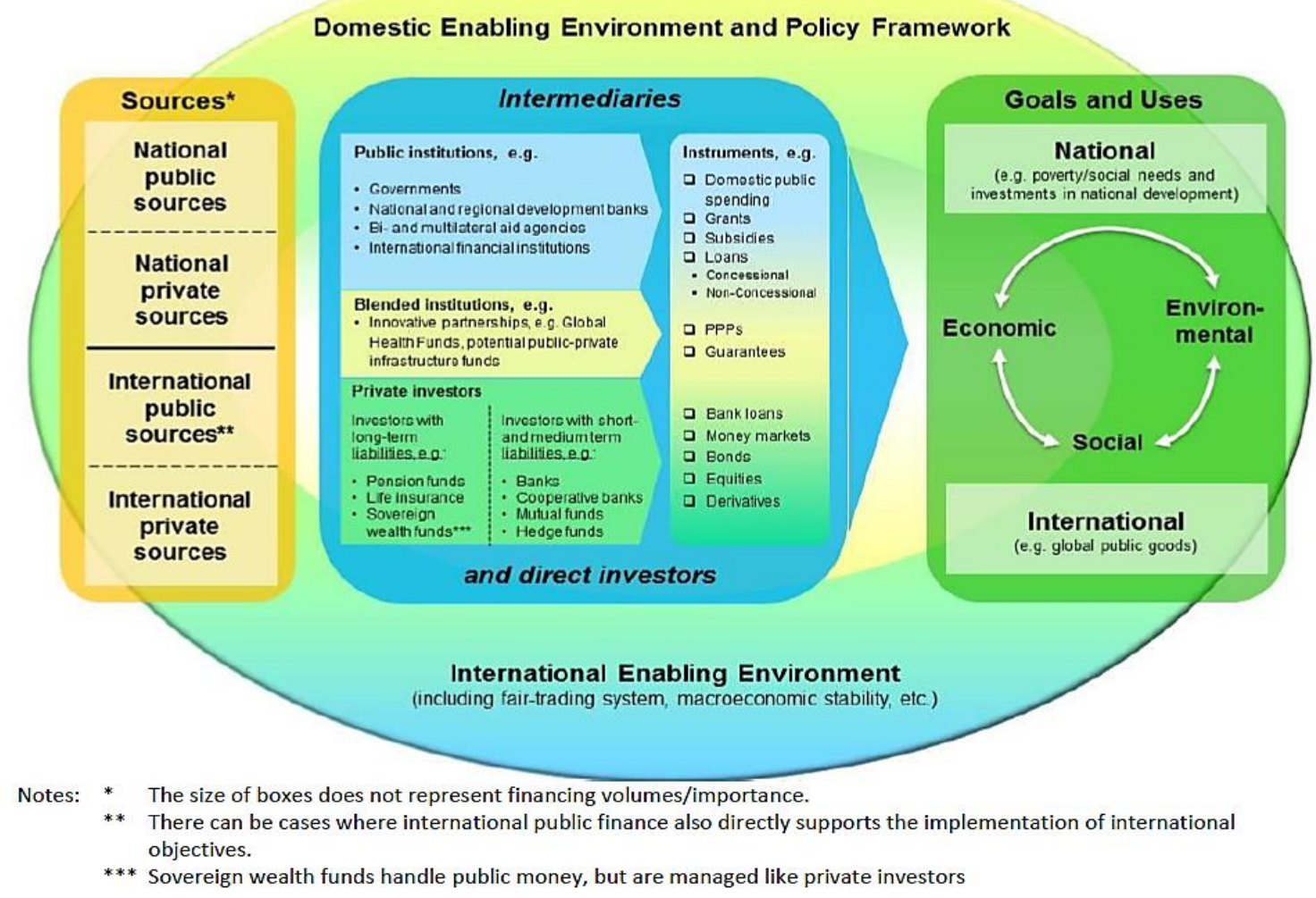

Source: ICESDF: UN 2014

Fig. 4: Flow of funds: international and national sources (ICESDF)

This phenomenon is also analogous for the governments of low-income countries. The banks and the bond markets are not sufficiently able to provide adequate capital obligatory to fulfill the basic needs. Moreover, the capital markets are careful to invest in poor countries fearing that conditions like defaulting or insolvency may arise (Schmidt-Traub, 2015). Thus, the capital required for achieving the SDGs in the majority of low-income countries remain vastly 'insufficient and inequitable', as capital is seeking a good return while investing in poor countries although the world collectively has sufficient liquidity (Sachs \& Schmidt-Traub, 2013).

Private companies are major sources of $R \& D$ and have gained expertise in "early-stage technology deployment, large-scale production systems, along with knowledge of the best practices for technology diffusion to low-income settings" (Schmidt-Traub, 2015). If there are suitable provisions of good interfaces to work with the public sector then many private companies are willing and quite able to accomplish the social objectives of sustainable development. Consequently, businesses can sometimes play an important role in improving 'social service delivery' if properly backed by public policies and regulations. Thus apt polices are indispensible to form an effective Public-Private Partnership (PPP) by combining public financing, public regulations, and private market participation.

The public finance may come from mainly two sources, firstly, the domestic sources and secondly, the
International Sources. Domestic sources cover up income taxes, indirect taxes, customs revenues, state-enterprise profits etc.. Increase in Domestic Budget Revenues (DBR), particularly at the local or municipal or state level, definitely helps for having a healthy domestic source of Public Finance. On the other hand, the International Sources of public finance envelope Official Development Assistance (ODA), Other Official Flows (OOF), public loans and additional Climate Finance (ODA-C, OOF-C). In accordance to the Monterrey Consensus (UN 2002) and the Busan Partnership for Effective Development Cooperation (2011), "the concessional international public finance should only be mobilized in areas where domestic public resources are insufficient, and business is unable to mobilize adequate private finance" (Schmidt-Traub, 2015).

Remittances are another sources of finance though remittances neither public finance nor 'transfer incomes' from rich households to poor households. Remittances are private flows (typically within families) of financing to support household investments and consumption expenditures (e.g. housing, small entrepreneurship, payment for food, school fees, or medical expenses etc.). They can be an important income source for poor households and can make a significant contribution towards reducing income poverty (Gupta et al. 2007). Remittance also has a deep drawback as it is both cause and consequence of 'braindrain' resulting to a tragic loss of family cohesion. 


\section{References}

1. Agarwal, A., \& Narain, S. Towards Green Villages -a strategy for environmentally sound and participatory rural development in India. Environment and Urbanization, 1992;4(1):53-64.

2. Bacon, N., Cochrane, D., Woodcraft, S., \& Brown, J. (2012). Creating Strong Communities: How to Measure the Social Sustainability of New Housing Developments. Retrieved from The Berkeley Group: https://www.berkeleygroup.co.uk/media/pdf/7/8/berkeleyreports-and-opinions-social-sustainability-reports-creatingstrong-communities-part-one.pdf

3. Barron, L., \& Gauntlett, E. (2002). Housing and Sustainable Communities Indicators Project: Stage 1 Report-Model of Social Sustainability. Retrieved from WACOSS (Western Australia Council of Social Services): http://wacoss. org. au/images/assets/SP_Sustainability/HSCIP\% 20Stage, 201

4. Basiago, A. Economic, social, and environmental sustainability in development theory and urban planning practice. The Environmentalist, 1999;19:145-161.

5. Bossel, H. (2000). Policy assessment and simulation of actor orientation for sustainable development. Ecological Economics, 2000;35(3):337-355.

6. Bramley, G., Dempsey, N., Power, S., Brown, C., \& Watkins, D. (2009, September). Social sustainability and urban form: evidence from five British cities. Environment and Planning A, 2009;41:2125-2142.

7. CASSE. (n.d.). Center for the advancement of the Steady State Economy. Retrieved November 8, 2016, from http://www.steadystate.org/discover/definition/

8. Castillo, H., Moobela, C., Price, A. D., \& Mathur, V. N. (2007). Assessing Urban Social Sustainability: Current Capabilities and Opportunities for Future Research. he International Journal of Environmental, Cultural, Economic and Social Sustainability, 2007;3(3):39-48.

9. Colantonio, A. (2007). Social Sustainability: An Exploratory Analysis of its Definitions, Assessment Methods, Metrics and Tools. EIRBURS Working Paper Series.

10. Colantonio, A. (2008). Measuring Social Sustainability: Best Practice from Urban Renewal in the EU. Oxford: Oxford Institute for Sustainable Development (OISD).

11. Colantonio, A. (2010). Urban social sustainability themes and assessment methods. Proceedings of the Institution of Civil Engineers - Urban Design and Planning, 2010;163:7988.

12. Colantonio, A. (2011). Social Sustainability: Exploring the Linkages Between Research, Policy and Practice. In C. C. Jaeger, J. D. Tàbara, \& J. Jaeger (Eds.), European Research on Sustainable Development (Volume 1: Transformative Science Approaches for Sustainability) (pp. 35-57). Springer Berlin Heidelberg.

13. Davidson, M. (2009). Social sustainability: a potential for politics? Local Environment, 2009;14(7):607-619.

14. Dempsey, N., Bramley, G., Power, S., \& Brown, C. The Social Dimension of Sustainable Development : Defining Urban Social Sustainability. Sustainable Development, 2009;19:289-300

15. Dixon, J. A., \& Fallon, L. A. (1989). The concept of sustainability: Origins, extensions, and usefulness for policy. Society \& Natural Resources, 73-84.

16. Dixon, T., \& Woodcraft, S. (2013). Creating strong communities - measuring social sustainability in new housing development. Town \& Country Planning, 473- 480.

17. Drakakis-Smith, D. (1995, May 1). Third World Cities: Sustainable Urban Development, 1. Urban Studies, 32(4-5), 659-677.
18. Freeman, C. Malthus with a computer. Futures, 1973;5(1):5-13.

19. Geography. (n.d.). What Is the Brown Agenda? Retrieved from Geography: http://geography.name/what-is-the-brownagenda/

20. Ghahramanpouri, A., Lamit, H., \& Sedaghatnia, S. Urban Social Sustainability Trends in Research Literature. Asian Social Science, 2013;9(4):185-193.

21. Goldsmith, E. (1974). Blueprint for survival. New American Library.

22. Guido, S.-T., \& Sachs, J. D. (2015). Financing Sustainable Development: Implementing the SDGs through Effective Investment Strategies and Partnerships. Sustainable Development Solutions Network (SDSN).

23. Hayes, B. (2012, May-June). Computation and the Human Predicament. American Scientist, 2012;100(3):186-191.

24. Holden, M. Urban Policy Engagement with Social Sustainability in Metro Vancouver. Urban Studies, 2012;49(3):527-542.

25. Jacobs, M. (1999). Sustainable Development as a Contested Concept. In A. Dobson (Ed.), Fairness and Futurity: Essays on Environmental Sustainability and Social Justice (p. 24). Oxford University Press.

26. Kahn, M. (1995). Concepts, definitions, and key issues in sustainable development: the outlook for the future. The 1995 International Sustainable Development Research Conference Manchester, England, Mar. 27]28,, (pp. 2-13). Manchester.

27. Keating, M. (1994). The Earth Summit's agenda for change : a plain language version of Agenda 21 and the other Rio Agreements (3rd ed.). Geneva: Geneva : Centre for Our Common Future, 1994.

28. Kurt, D. (2018, May 3). What is Finance? Retrieved October 3, 2018, from Investopedia: https://www.investopedia.com/ask/answers/what-is-finance/

29. Layard, R. (2007, June 30). Against unhappiness. Retrieved January 5, 2017, from Prospect:

https://www.prospectmagazine.co.uk/magazine/againstunha ppiness

30. Maloutas, T. (2003). Promoting social sustainability : The case of Athens. City, 2003;7(2):167-181.

31. McKenzie, S. (2004). Social Sustainability : Towards Some Definitions. Magill, South Australia: Hawke Research Institute, University of South Australia,

32. Meadows, D. H., Meadows, D. L., Randers, J., \& Behrens III, W. W. (1972). The Limits to Growth. New York: Universe Books.

33. Neamţu, B. (2012). Measuring the social sustainability of urban communities: the role of local authorities. Transylvanian Review of Administrative Sciences, 112-127.

34. Ormerod, P. (2007, April 29). Against happiness. Retrieved January 5, 2017, from Prospect: http://www.prospectmagazine.co.uk/magazine/againsthappi ness

35. Partridge, E. (2005). Social sustainability': a useful theoretical framework? Australasian Political Science Association Annual Conference 2005. Dunedin, New Zealand.

36. Pawłowski, A. How many dimensions does sustainable development have? Sustainable Development, 2007;16(2):81-83.

37. Polèse, M., \& Stren, R. E. (2000). Understanding the New Sociocultural Dynamics of Cities: Comparative Urban Policy in a Global Context. In M. Polèse, \& R. E. Stren (Eds.), The Social Sustainability of Cities: Diversity and the Management of Change (pp. 3-38). Toronto: University of Toronto Press. 
38. Sachs, J., \& Schmidt-Traub, G. (2013). Financing for development and climate change post-2015. Paris and New York: Sustainable Development Solutions Network (SDSN).

39. Schmidt-Traub, G. (2015). Investment Needs to Achieve the Sustainable Development Goals : Understanding the Billions and Trillions. Sustainable Development Solutions Network (SDSN). Retrieved from http://unsdsn.org/resources/publications/sdg-investmentneeds/

40. Sengupta, I., \& Baranwal, V. (2012, December). Sustainability in Urban Development: An Indian Standpoint. Management Insight, VIII(2).

41. Spangenberg, J. H., \& Omann, I. Assessing social sustainability: social sustainability and its multicriteria assessment in a sustainability. International Journal of Innovation and Sustainable Development (IJISD), 2006;1(4):318-348.

42. UN General Assembly. (2015). Resolution adopted by the General Assembly on 27 July 2015. Sixty-ninth session Agenda item 18, (pp. 1-2)

doi:http://www.un.org/en/development/desa/population/mig ration/generalassembly/docs/globalcompact/A_RES_69_31 3.pdf

43. United Nations. (2015). Transforming Our World: The 2030 Agenda for Sustainable Development. A/RES/70/1 (p. 14). United Nations. Retrieved from www.sustainabledevelopment.un.org

44. UNSD. (1992). Agenda 21. United Nations Conference on Environment \& Development Rio de Janerio, Brazil, 3 to 14 June 1992. Rio de Janerio, Brazil: UN.
45. WACOSS . (n.d.). WACOSS Model of Social Sustainability. Retrieved March 2, 2017, from Western Australian Council of Social Services (WACOSS):

http://www.wacoss.org.au/Libraries/State_Election_2013_D ocuments/WACOSS_Model_of_Social_Sustainability.sflb.a shx

46. WCED. (1987). UN Documents : Gathering a Body of Global Agreements. Retrieved from Report of the World Commission on Environment and Development: Our Common Future: http://www.un-documents.net/wcedocf.htm

47. Yiftachel, O., \& Hedgcock, D. (1993, May). Urban social sustainabilityThe planning of an Australian city. Cities, 10(2), 139-157. Retrieved from https://doi.org/10.1016/0264-2751(93)90045-K.

48. Yung, E. H., Chan, E. H., \& Xu, Y. (2011). Sustainable Development and the Rehabilitation of a Historic Urban District - Social Sustainability in the Case of Tianzifang in Shanghai. Sustainable Development, 2011;22(2):95-112.

How to cite this article: Majumder K. G, Chakraborti M. Financing sustainable development: Needs and ways. J Manag Res Anal. 2018;5(4):477-484. 